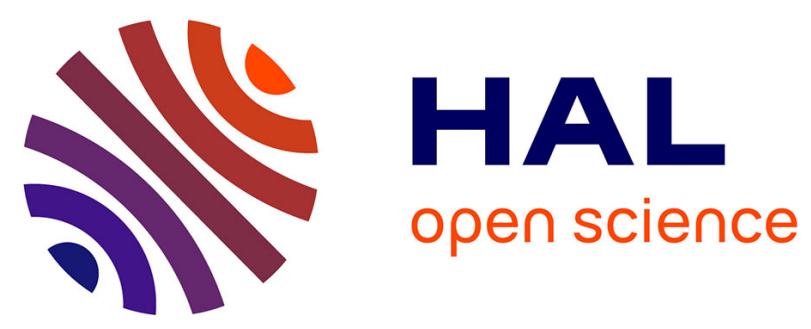

\title{
Ti-Catalyst Biomimetic Sensor for the Detection of Nitroaromatic Pollutants
}

\author{
Alizée Lemaire, Philippe Hapiot, Florence Geneste
}

\section{To cite this version:}

Alizée Lemaire, Philippe Hapiot, Florence Geneste. Ti-Catalyst Biomimetic Sensor for the Detection of Nitroaromatic Pollutants. Analytical Chemistry, 2019, 91 (4), pp.2797-2804. 10.1021/acs.analchem.8b04671 . hal-02015559

HAL Id: hal-02015559

https://hal-univ-rennes1.archives-ouvertes.fr/hal-02015559

Submitted on 14 Feb 2019

HAL is a multi-disciplinary open access archive for the deposit and dissemination of scientific research documents, whether they are published or not. The documents may come from teaching and research institutions in France or abroad, or from public or private research centers.
L'archive ouverte pluridisciplinaire HAL, est destinée au dépôt et à la diffusion de documents scientifiques de niveau recherche, publiés ou non, émanant des établissements d'enseignement et de recherche français ou étrangers, des laboratoires publics ou privés. 


\title{
Ti Catalyst Biomimetic Sensor for the Detection of Nitroaromatic Pollutants
}

\author{
Alizée Lemaire, Philippe Hapiot, Florence Geneste* \\ Univ Rennes, CNRS, ISCR (Institut des Sciences Chimiques de Rennes) - UMR 6226, F-35000 \\ Rennes, France.
}

\begin{abstract}
An electrode modified by a Ti complex in Nafion ${ }^{\circledR}$ was used in the electrochemical detection of nitroaromatic compounds (NACs). The catalyst reduces nitroaromatic groups by a 6-electron process and with a high apparent rate constant $k_{l}$ that was estimated to be at least $19000 \mathrm{~mol}^{-1}$ $\mathrm{L} \mathrm{s}^{-1}$ by simulation of the first step of the cathodic reduction of 4-nitrophenylacetic acid used as model molecule. The modified electrode was prepared and optimized in terms of Nafion ${ }^{\circledR}$ and catalyst concentrations. In the chosen analytical medium, the Ti catalyst-containing electrode shows a good stability in the presence of nitro species. A standard deviation around $15 \%$ was calculated on the analysis performed with 28 different modified electrodes, which could be expected for a drop-coating process. We show that the modified electrode detects several nitroaromatic compounds such as nitrophenols, mononitroaniline and dinitrotoluene with detection limits ranging from 1 to $9 \times 10^{-4} \mathrm{~g} \mathrm{~L}^{-1}\left(0.2-5.1 \times 10^{-6} \mathrm{~mol} \mathrm{~L}^{-1}\right)$. As an interesting feature, the sensor exhibits a good selectivity towards NACs detection since titanocene did not catalyze the reduction of nitroaliphatic compounds.
\end{abstract}

Keywords : Nitroaromatic pollutants, Titanocene, Nafion, Biomimetic sensor, NAC index

Nitroaromatic compounds (NACs) are unnatural species that came in the environment owing to anthropogenic activities such as manufacturing and use of dyes, pesticides, pharmaceuticals and explosives. The nitro group is well-known to reduce the biodegradability of molecules. ${ }^{1}$ NACs are biorecalcitrant molecules that could accumulate in soils and groundwater ${ }^{2}$ and that are often highly toxic and mutagenic. ${ }^{3}$ Molecules such as nitrobenzene, 2,4-dinitrotoluene, mononitrophenols and mononitroanilines have for example been classified by US environmental protection agency as priority pollutants. ${ }^{4}$

Reliable and highly sensitive analytical methods are therefore necessary for controlling environmental pollution. Various techniques have been developed for the detection of NACs, such as florescence, ${ }^{5}$ chromatography ${ }^{6}$ and ion mobility spectrometry. ${ }^{7}$ 
The direct electrochemical reduction of nitroaromatic groups in aqueous medium gives hydroxylamine by a 4-electron process, the high stoichiometry being an advantage for the sensibility of the sensor. This interesting feature added to intrinsic properties of electrochemical sensors such as low-cost instrumentation, portability, simplicity to operate, short analysis time as well as high sensitivity and reliability makes those sensors promising analytical tools for NACs detection. Carbon materials such as graphene and carbon nanotubes have been used to prepare sensors for detecting NACs. ${ }^{8}$ These materials are particularly efficient for the enhancement of electron transfer and their high surface hydrophobicity leads to strong adsorption of organic contaminants, especially the aromatic ones via $\pi-\pi$ stacking. ${ }^{9}$ Nanomaterials such as metallic nanoparticles have also proved their efficiency thanks to their high electroactive surface area and their catalytic properties. ${ }^{10}$ These electrode materials could be combined with receptor sites to allow a preconcentration of NACs on the electrode surface with an enhancement of the selectivity. For example, cyclodextrin, ${ }^{11}$ porphyrins, ${ }^{12}$ peptides ${ }^{13}$ or porous matrices such as mesoporous silica, ${ }^{14}$ ionic liquid ${ }^{15}$ and molecularly imprinted polymers ${ }^{16}$ have been considered. Even if preconcentration methods allow the preparation of sensors with high sensitivities, the selectivity can only really be achieved through specific receptors such as molecularly imprinted polymers. ${ }^{16-17}$ Another method that gives rise to highly sensitive and selective sensors is the use of catalysts that are specific to the reduction of nitro compounds. Biosensors have been prepared with nitroreductases in the presence of a mediator such as nicotinamide adenine dinucleotide (NADH) or $N$-(3-pyrrol-1-ylpropyl)-4,4'-bipyridine for NACs detection. ${ }^{18}$ Thanks to the fast kinetic rate of the enzyme, limits of detection around $2 \mu \mathrm{mol} \mathrm{L}-1$ have been reported for 2,4-dinitrotoluene and 2,4,6-trinitrotoluene.

An interesting alternative to enzymes is the use of molecular catalysts. They offer the advantages of a more efficient electronic transfer compared to enzymes based systems that often require mediators, moreover they are less expensive, more stable against time, $\mathrm{pH}$ and temperature variations. The term "enzyme-less biosensor" has been previously attributed to this kind of sensor. ${ }^{19}$

We have previously reported the interest of titanocene dichloride $\left(\left(\mathrm{C}_{5} \mathrm{H}_{5}\right)_{2} \mathrm{TiCl}_{2}\right)$ for the electrochemical reduction of biorecalcitrant pesticides containing a nitro group. ${ }^{20} \mathrm{We}$ have also shown that it keeps its catalytic activity when immobilized on graphite felt electrodes by encapsulation in a Nafion film. The catalyst allowed the reduction of nitroaromatic pollutants into amino derivarives, allowing the enhancement of the biodegradability of the solution. In this work, we took advantage of the interesting catalytic properties of the titanocene complex that is able to reduce nitro groups by a 6-electron process to develop a sensor for NACs 
detection. To our knowledge, this constitutes the first example of sensor based on the use of synthetic catalyst for NACs detection. A kinetic study of the reaction between this catalyst and a nitroaromatic compound underlines its high catalytic efficiency and so the interest to use it for NACs detection. The sensor was prepared by the immobilization of the complex in a Nafion ${ }^{\circledR}$ film. This perfluorinated ion-exchange polymer is well-known for its good proton conductivity, its mechanical stability, and its ability to preconcentrate species on the electrode surface. ${ }^{19}$ The preparation of the sensor was optimized in terms of sensitivity and stability. Its ability to detect different nitro derivatives was then evaluated.

\section{MATERIALS AND METHODS}

Voltammetric experiments were carried out using a SP50 (Biologic) potentiostat/galvanostat. A glassy carbon electrode (diameter $3 \mathrm{~mm}$ ), a platinum wire auxiliary electrode, and a saturated calomel reference electrode were used in a standard three-electrode configuration. Cyclic voltammetry was carried out in sulfuric acid based electrolyte or NAC solutions, under an argon atmosphere. For comparison with numerical simulations, the background current obtained from a blank solution was subtracted from the voltammograms. Between analyses, the modified electrodes were rinsed with a $\mathrm{pH} 3$ solution.

Numerical simulations of the voltammograms were performed with the KISSA 1D program10 using the default numerical options with the assumption of planar diffusion. Butler-Volmer law was considered for the electron transfer kinetics ${ }^{21}$ and the transfer coefficient, $\alpha$, was taken as 0.5 . The iR-drop was compensated by using the positive feedback function of the potentiostat.

\section{RESULTS AND DISCUSSION}

Preparation of the modified electrode and optimization steps. Titanocene undergoes spontaneous hydrolysis in aqueous medium into $\left(\mathrm{C}_{5} \mathrm{H}_{5}\right)_{2} \mathrm{Ti}^{\mathrm{IV}}\left(\mathrm{OH}_{2}\right)_{2}{ }^{2+}$ that can be electrochemically reduced into its active form $\left(\mathrm{C}_{5} \mathrm{H}_{5}\right)_{2} \mathrm{Ti}^{\mathrm{iII}}\left(\mathrm{OH}_{2}\right)_{2}{ }^{+}$. Cyclic voltammetry analyses show that titanocene in a $0.5 \mathrm{~mol} \mathrm{~L}^{-1} \mathrm{H}_{2} \mathrm{SO}_{4}$ exhibits a reversible Ti ${ }^{\mathrm{IV} / \mathrm{III}}$ system (equation 1 ) at $\mathrm{E}^{\circ}=-0.44 \mathrm{~V} / \mathrm{SCE}$ with a peak-to-peak potentials separation $\Delta \mathrm{Ep}$ close to $60 \mathrm{mV}$ (Figure 1a).

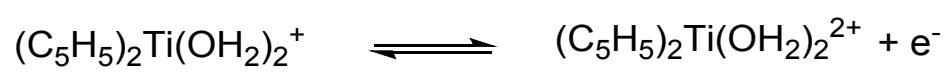




\section{Nafion ${ }^{\circledR}$ concentration}

The electrode was modified by drop-casting a solution containing both titanocene and Nafion ${ }^{\circledR}$ onto a glassy carbon electrode. The immobilization process of titanocene was optimized, firstly by varying the initial concentration of $\mathrm{Nafion}^{\circledR}$ in ethanol $(1.25,2.5$ and $3.75 \%)$ with a titanocene concentration of $0.05 \mathrm{~g} \mathrm{~L}^{-1}\left(2 \times 10^{-4} \mathrm{~mol} \mathrm{~L}^{-1}\right)$. The immobilized $\left(\mathrm{C}_{5} \mathrm{H}_{5}\right)_{2} \mathrm{Ti}^{\mathrm{iV}}\left(\mathrm{OH}_{2}\right)_{2}{ }^{2+}$ complex was analyzed by cyclic voltammetry (Figure S1). The electrochemical signal evolved during the successive first scans and led to a well-defined reversible system after cycling. This behavior is typical of titanocene/Nafion ${ }^{\circledR}$-modified electrodes. ${ }^{20 \mathrm{~b}}$ It could be due to the reduction during cycling of dioxygen that is difficult to remove from the membrane. This phenomenon was even more pronounced with electrodes modified with a high concentration of Nafion ${ }^{\circledR}$. Indeed, after a first conditioning step of 11 cycles (Figure 1b), a second analysis required 10 cycles to obtain again a well-defined reversible system with an electrode modified by $3.75 \%$ of Nafion ${ }^{\circledR}$, whereas only 2 cycles are enough when the electrode was modified by a Nafion ${ }^{\circledR}$ solution of $2.5 \%$ and $1.25 \%$.

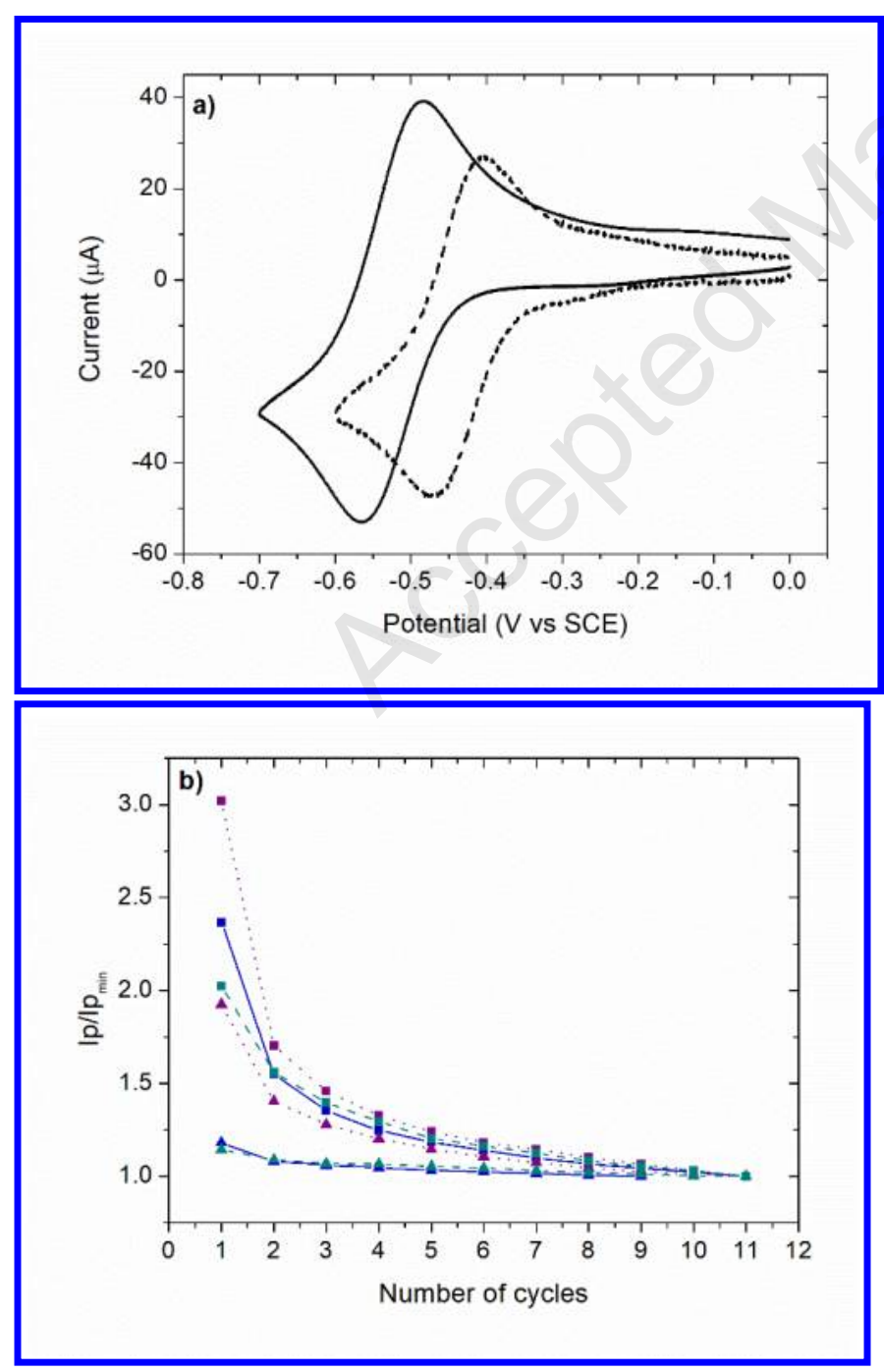




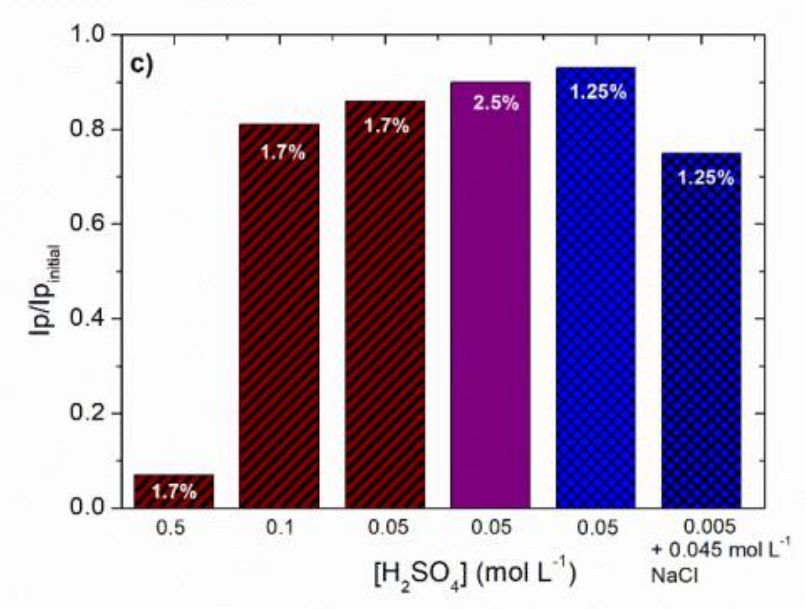

Figure 1. a) Cyclic voltammograms of the titanocene complex $\left(4 \times 10^{-3} \mathrm{~mol} \mathrm{~L}^{-1}\right)$ on glassy carbon electrode ( $3 \mathrm{~mm}$ diameter) in $0.5 \mathrm{~mol} \mathrm{~L}^{-1} \mathrm{H}_{2} \mathrm{SO}_{4}$ (dotted line), and on the Nafionmodified electrode $\left([\mathrm{Nafion}]=2.5 \%\right.$ and $\left.\left[\left(\mathrm{C}_{5} \mathrm{H}_{5}\right)_{2} \mathrm{TiCl}_{2}\right]=4 \times 10^{-3} \mathrm{~mol} \mathrm{~L}^{-1}, 11^{\text {th }} \mathrm{scan}\right)$ in 0.05 mol L-1 $\mathrm{H}_{2} \mathrm{SO}_{4}$ (solid line). Scan rate: $100 \mathrm{mV} \mathrm{s}^{-1}$ b) Reduction peak current Ip normalized to the reduction peak current after stabilization $I p_{\min } v s$ the number of cycles obtained in cyclic voltammetry for titanocene-modified electrodes prepared with solutions of $2 \times 10^{-4} \mathrm{~mol} \mathrm{~L}^{-1}$ of titanocene and $1.25 \%(-), 2.5 \%$ (---) or $3.75 \%$ (....) of Nafion ${ }^{\circledR}$. The analysis was performed with a newly modified electrode (- - -) and after a first stabilization using 11 cycles (- $\boldsymbol{\Lambda}_{-}$) c) Reduction peak current Ip normalized to the initial reduction peak current vs the $\mathrm{H}_{2} \mathrm{SO}_{4}$ electrolyte concentration $\mathrm{Ip}_{\text {initial }}$ obtained in cyclic voltammetry after $60 \mathrm{~min}$ of immersion of titanocene-modified electrodes prepared with solutions of $1.3 \mathrm{~g} \mathrm{~L}^{-1}\left(5.2 \times 10^{-3} \mathrm{~mol} \mathrm{~L}^{-1}\right)$ (hatched), $1 \mathrm{~g} \mathrm{~L}^{-1}\left(4.0 \times 10^{-3} \mathrm{~mol} \mathrm{~L}^{-1}\right)$ (none) and $0.05 \mathrm{~g} \mathrm{~L}^{-1}\left(2.0 \times 10^{-4} \mathrm{~mol} \mathrm{~L}^{-1}\right)$ (cross-hatched) of titanocene. Nafion ${ }^{\circledR}$ concentrations are indicated on the column graph.

Nafion ${ }^{\circledR}$ concentrations lower or equal to $2.5 \%$ are therefore favorable and a preconditioning step of at least 10 cycles in $0.05 \mathrm{~mol} \mathrm{~L}^{-1} \mathrm{H}_{2} \mathrm{SO}_{4}$ is required before each measurement with a newly prepared modified electrode.

It is worth noting that the $\mathrm{E}^{\circ}$ of the $\mathrm{Ti}^{\mathrm{IV} / \mathrm{III}}$ reversible system is at $-0.53 \mathrm{~V} / \mathrm{SCE}$ when immobilized in the Nafion ${ }^{\circledR}$ film whereas it is at $-0.44 \mathrm{~V} / \mathrm{SCE}$ in solution (Figure 1a). This cathodic shift of $90 \mathrm{mV}$ is probably due to the reference electrode that is dipped in the solution and not in the Nafion ${ }^{\circledR}$ medium. A shift of $170 \mathrm{mV}$ was also observed for example with 1,1'Ferrocenedimethanol with a system observed at $0.27 \mathrm{~V} / \mathrm{SCE}$ on glassy carbon electrode and at $0.10 \mathrm{~V} / \mathrm{SCE}$ on a glassy carbon electrode covered by a Nafion film. 


\section{$\left(\mathrm{C}_{5} \mathrm{H}_{5}\right)_{2} \mathrm{Ti}^{\mathrm{IV}}\left(\mathrm{OH}_{2}\right)_{2}{ }^{2+}$ complex concentration}

The sensitivity of the sensor is directly linked to its catalytic activity towards the reduction of NACs. The effect of the catalyst concentration on the sensor sensitivity was also tested (Figure S2). The concentration of catalyst should be low enough to detect low concentrations of nitro compounds but high enough to obtain a well-defined electrochemical signal of titanocene. While no change $\left(\mathrm{Ip} / \mathrm{Ip}^{\circ}=1\right)$ was observed on the voltammogram after addition of a $5.5 \times 10^{-5}$ mol L-1 solution of 4-nitrophenylacetic acid when a concentration of $1 \mathrm{~g} \mathrm{~L}^{-1}\left(4 \times 10^{-3} \mathrm{~mol} \mathrm{~L}^{-1}\right)$ of titanocene was used to prepare the electrode, a decrease of the concentration by a factor 10 allows a significant increase of the reduction peak current intensity Ip compared with $\operatorname{Ip}^{\circ}$. The $\mathrm{Ip} / \mathrm{Ip}^{\circ}$ ratio was even higher (3.06) for a concentration of $0.02 \mathrm{~g} \mathrm{~L}^{-1}\left(8 \times 10^{-5} \mathrm{~mol} \mathrm{~L}^{-1}\right)$ of titanocene. This concentration of $0.02 \mathrm{~g} \mathrm{~L}^{-1}\left(8 \times 10^{-5} \mathrm{~mol} \mathrm{~L}^{-1}\right)$ was chosen to achieve the calibration curve corresponding to a good compromise to obtain a good resolution of the voltammogram and a high value of $\mathrm{Ip} / \mathrm{Ip}^{\circ}$.

\section{Electrolyte}

The $\left(\mathrm{C}_{5} \mathrm{H}_{5}\right)_{2} \mathrm{Ti}^{\mathrm{IV}}\left(\mathrm{OH}_{2}\right)_{2}{ }^{2+}$ complex is stable in $\mathrm{pH}<4$ aqueous solutions and loses a cyclopentadienyl group at neutral $\mathrm{pH} .{ }^{22}$ The effect of the $\mathrm{H}_{2} \mathrm{SO}_{4}$ electrolyte concentration on the electrochemical signal of titanocene encapsulated in the Nafion ${ }^{\circledR}$ film was thus checked by cyclic voltammetry for $\mathrm{pH}<4$. The electrochemical signal was measured after a preconditioning step and after dipping 60 min the electrode in the electrolyte solution (Figure $1 c)$.

The electrochemical signal remained stable at more than $80 \%$ in solutions with concentrations lower than $0.1 \mathrm{~mol} \mathrm{~L}^{-1}$, whereas it significantly decreased in $0.5 \mathrm{~mol} \mathrm{~L}^{-1} \mathrm{H}_{2} \mathrm{SO}_{4}$ electrolyte. For $\mathrm{H}_{2} \mathrm{SO}_{4}$ concentrations of $0.05 \mathrm{~mol} \mathrm{~L}^{-1}$, a good stability (around 85-92\%) is obtained regardless of the concentration of Nafion ${ }^{\circledR}$ used to modify the electrode $(1.25,1.7$ or $2.5 \%)$. The possibility to decrease the concentration of $\mathrm{H}_{2} \mathrm{SO}_{4}$ by a factor 10 was tested adding sodium chloride to assure a good conductivity. Whereas a good stability was obtained in $0.05 \mathrm{~mol} \mathrm{~L}^{-1} \mathrm{H}_{2} \mathrm{SO}_{4}$, a loss of $25 \%$ of the initial signal was observed in the presence of $\mathrm{NaCl}$. This decrease could be due to the high concentration of $\mathrm{Na}^{+}$in solution that favors $\mathrm{Na}^{+}$exchange between the electrolyte medium and the Nafion ${ }^{\circledR}$ film, leading to the leaching of the $\left(\mathrm{C}_{5} \mathrm{H}_{5}\right)_{2} \mathrm{Ti}^{\mathrm{IV}}\left(\mathrm{OH}_{2}\right)_{2}{ }^{2+}$ complex in solution. 
Kinetics of nitro reduction by titanocene. We fully studied the catalysis of the $\left(\mathrm{C}_{5} \mathrm{H}_{5}\right)_{2} \mathrm{Ti}^{\mathrm{IV}}\left(\mathrm{OH}_{2}\right)_{2}{ }^{2+}$ complex in $\mathrm{H}_{2} \mathrm{SO}_{4}$ to determine the kinetic parameters before doing the study with the Ti complex immobilized in Nafion. The voltammograms of the reduction of the $\left(\mathrm{C}_{5} \mathrm{H}_{5}\right)_{2} \mathrm{Ti}^{\mathrm{IV}}\left(\mathrm{OH}_{2}\right)_{2}{ }^{2+}$ complex were recorded for different concentrations of 4-nitrophenylacetic acid and at different scan rates. As general observations, the cathodic peak current of the Ti complex considerably increases with the concentration of nitro compound in the range of investigated scan rates $\left(0.05-0.4 \mathrm{~V} \mathrm{~s}^{-1}\right)$ (Figure 2). The same experiments were performed with a titanocene-modified electrode and show a similar behavior (Figure S3).

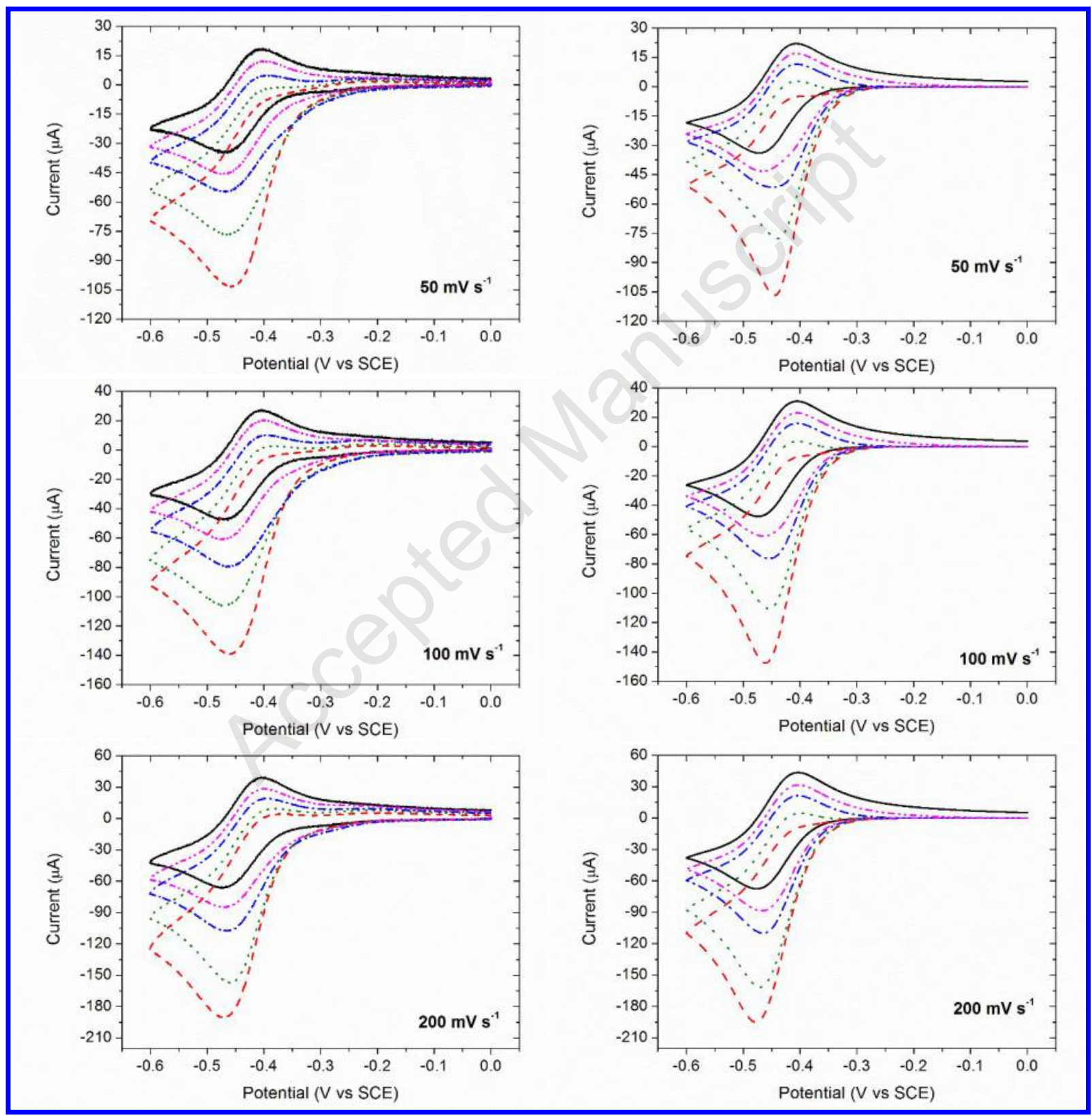




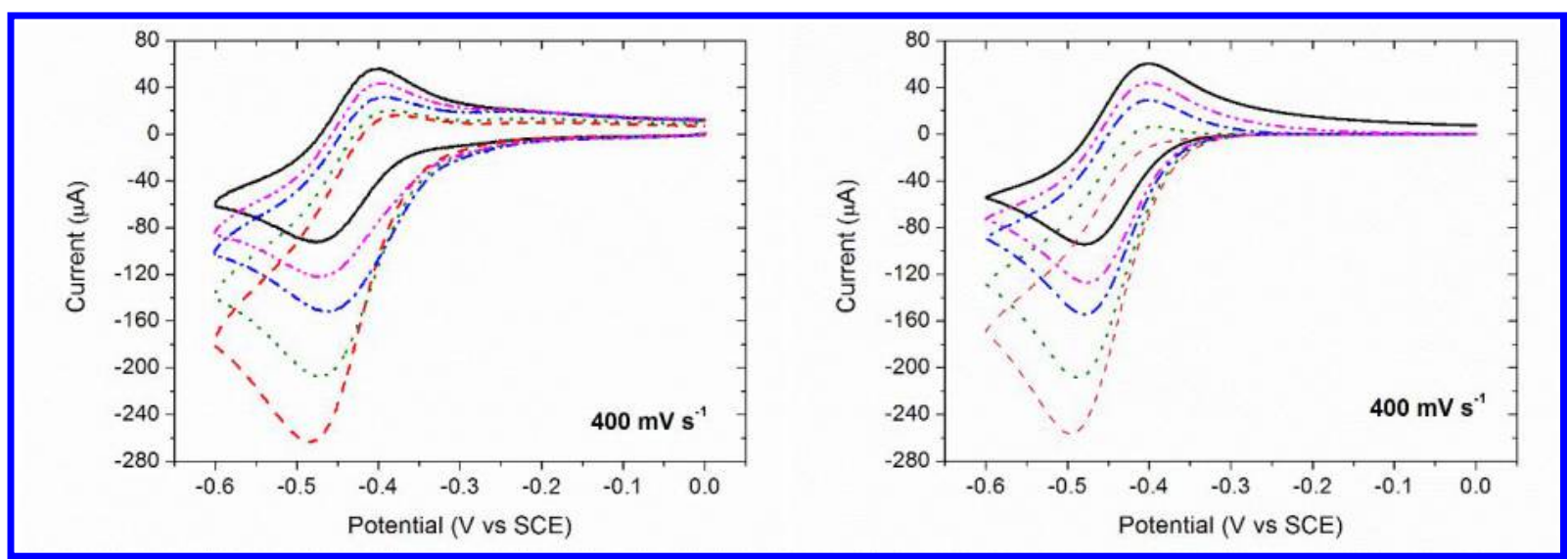

Figure 2. Cyclic voltammograms of titanocene $\left(1 \mathrm{~g} \mathrm{~L}^{-1}, 4 \times 10^{-3} \mathrm{~mol} \mathrm{~L}^{-1}\right)$ in $0.5 \mathrm{~mol} \mathrm{~L}^{-1} \mathrm{H}_{2} \mathrm{SO}_{4}$ before (-) and after addition of $2.8 \times 10^{-4} \mathrm{~mol} \mathrm{~L}^{-1}\left(--^{--}\right), 5.5 \times 10^{-4} \mathrm{~mol} \mathrm{~L}^{-1}\left(-^{--}\right), 1.1 \times 10^{-3} \mathrm{~mol}$ $\mathrm{L}^{-1}(\ldots .),. 1.6 \times 10^{-3} \mathrm{~mol} \mathrm{~L}^{-1}(----)$ 4-nitrophenylacetic acid on a $3 \mathrm{~mm}$ diameter glassy carbon electrode (left). Simulations of voltammograms considering all the reduction steps after the first one as fast and $k_{1}=1.9 \times 10^{4} \mathrm{~mol}^{-1} \mathrm{~L} \mathrm{~s}^{-1}$ (right). The background was subtracted.

For titanocene without NACs, the intensity of the peak current varies linearly as a function of the square root of the scan rates (Figure S4) as expected for a diffusion-limited process. A diffusion coefficient of $3.4 \times 10^{-6} \mathrm{~cm}^{2} \mathrm{~s}^{-1}$ was derived in homogeneous solution from the slope of the best fit straight line assuming a fast electron transfer (Figure S4). This value is lower than those reported in acetonitrile for titanocene $\left(1.4-1.6 \times 10^{-5} \mathrm{~cm}^{2} \mathrm{~s}^{-1}\right)^{23}$ but is in the same order of magnitude as values obtained for similar size complexes in aqueous solutions ${ }^{24}$ owing probably to the solvation effect.

When titanocene is immobilized into a Nafion ${ }^{\circledR}$ film, a linear dependence between current and the square root of the scan rate is also observed, showing that the mass transport process follows the diffusion Fick's laws in the film as it does in solution. An apparent charge transfer rate between the catalyst and the nitro compound $\left(k_{l}\right)$ was estimated in homogeneous solution from simplified numerical simulations of the voltammograms of Figure 2. To simplify, an outersphere mechanism presented on Scheme 1 was considered. It involves a monoelectronic charge transfer between the Ti catalyst and the nitro substrate. From cyclic voltammetry analysis of titanocene, assuming a Buttler-Volmer law and considering the reduction peak current value and the peak-to-peak potential separation between the cathodic and anodic scans, ${ }^{25}$ the electrochemical apparent charge transfer standard rate constant $k_{s}$ was estimated at $0.016 \mathrm{~cm} \mathrm{~s}^{-1}$ (the charge transfer coefficient was considered as $\alpha=0.5$ ). This value is in the same order of magnitude than other organometallic complexes used as redox catalysts ${ }^{24,26}$ but is much lower 
than the fast ferrocene/ferrocenium system that has been reported to be $1 \mathrm{~cm} \mathrm{~s}^{-1}$ in organic medium. ${ }^{27}$

$$
\begin{aligned}
& \left(\mathrm{C}_{5} \mathrm{H}_{5}\right)_{2} \mathrm{Ti}\left(\mathrm{OH}_{2}\right)_{2}{ }^{2+}+\mathrm{e}^{-} \rightleftharpoons\left(\mathrm{C}_{5} \mathrm{H}_{5}\right)_{2} \mathrm{Ti}\left(\mathrm{OH}_{2}\right)_{2}{ }^{+} \quad k_{s} \\
& \left(\mathrm{C}_{5} \mathrm{H}_{5}\right)_{2} \mathrm{Ti}\left(\mathrm{OH}_{2}\right)_{2}{ }^{+}+\mathrm{RNO}_{2} \longrightarrow\left(\mathrm{C}_{5} \mathrm{H}_{5}\right)_{2} \mathrm{Ti}\left(\mathrm{OH}_{2}\right)_{2}{ }^{2+}+\mathrm{RNO}_{2}^{\cdot-} \quad k_{1}
\end{aligned}
$$

Scheme 1. Outer-sphere mechanism considered for the catalytic reduction of 4nitrophenylacetic acid by the titanocene complex to simulate cyclic voltammograms.

The first reduction step was taken as the rate-determining step, since the neutral radical is generally easier to reduce than the starting nitro compound in an outer-sphere mechanism. ${ }^{28}$ In order to simplify, the other steps leading to the formation of the amino derivative by the 6electron reduction process (4) were considered as fast.

$$
\mathrm{RNO}_{2}+6 \mathrm{e}^{-}+6 \mathrm{H}^{+} \longrightarrow \mathrm{RNH}_{2}+2 \mathrm{H}_{2} \mathrm{O}
$$

Simulated voltammograms display a reasonable agreement with the experimental ones (Figure 2) when an apparent chemical rate constant $k_{l}$ of $1.9 \times 10^{4} \mathrm{~mol}^{-1} \mathrm{~L} \mathrm{~s}^{-1}$ was used. This value is in the same order of magnitude than the apparent chemical rate constants previously estimated for immobilized nitroreductase ranging from $1.3 \times 10^{4}$ to $7.3 \times 10^{4} \mathrm{~mol}^{-1} \mathrm{~L} \mathrm{~s}^{-1}$ depending on the nitro substrate. ${ }^{18 a}$ This result underlines the high catalytic ability of the Ti complex towards the reduction of nitroaromatic compounds.

A theoretical highest apparent chemical rate constant for the titanocene complex of $5.8 \times 10^{5}$ $\mathrm{mol}^{-1} \mathrm{~L} \mathrm{~s}^{-1}$ could be estimated considering an outer-sphere mechanism, which is 30 times higher than the value found for the apparent chemical rate constant $k_{l}$. On the sole basis of these data, we cannot discriminate between the occurrence of an outer or inner-sphere mechanisms. However, since nitroaromatic reduction catalyzed by titanocene avoids the formation of hydroxylamine intermediates, ${ }^{29}$ an inner-sphere mechanism could be expected for the reduction of nitro species catalyzed by the Ti complex.

The kinetic study of titanocene immobilized in the Nafion ${ }^{\circledR}$ film requires to know the concentration of the Ti complex. It was estimated to be $0.14 \mathrm{~mol} \mathrm{~L}^{-1}$ from the amount of deposited titanocene ( $20 \mu \mathrm{L}$ of a $4.0 \times 10^{-3} \mathrm{~mol} \mathrm{~L}^{-1}$ titanocene solution) and the volume of the Nafion ${ }^{\circledR}$ film (cylinder of $6 \mathrm{~mm}$ diameter and $20 \mu \mathrm{m}$ thickness). However, when immersed in aqueous solution, the Nafion film is swelling and its volume increases, causing a decrease of 
the concentration. A better estimation can be done by simulation of voltammograms presented in Figure S3. A similar catalytic behavior to the one in solution can be expected comparing voltammograms of titanocene in solution after addition of 4-nitrophenylacetic acid (Figure 2) and when immobilized (Figure S3). Considering therefore the same apparent chemical rate constant $k_{l}$ of $1.9 \times 10^{4} \mathrm{~mol}^{-1} \mathrm{~L} \mathrm{~s}^{-1}$ for the catalytic reduction of the nitro group, a concentration of $0.12 \mathrm{~mol} \mathrm{~L}^{-1}$ could be measured for the immobilized catalyst. It is worth noting that for a better accuracy, direct reduction of the nitro group was also considered in these simulations since voltammograms at $0.05 \mathrm{~V} \mathrm{~s}^{-1}$ showed a peakbroadening. From the slope of Figure $\mathrm{S} 4$, an apparent diffusion coefficient of $5 \times 10^{-9} \mathrm{~cm}^{2} \mathrm{~s}^{-1}$ was found. The low mass transport of titanocene dichloride in the Nafion ${ }^{\circledR}$ film compared with homogeneous solution is consistent with literature..$^{26,30}$ The electrochemical apparent charge transfer standard rate constant $k_{s}$ of titanocene was also determined when the catalyst is immobilized in a Nafion ${ }^{\circledR}$ film. A much lower value, $2.5 \times 10^{-4} \mathrm{~cm} \mathrm{~s}^{-1}$, was found that is consistent with the existence of interactions between the electroactive sites, as it has been previously mentioned. ${ }^{26}$ The catalyst/substrate ratio deduced from simulation confirms the expected preconcentration of the nitro compound in the Nafion ${ }^{\circledR}$ film by a factor of 3 .

Thus, the apparent charge transfer standard rate constant $k_{s}$ of the catalyst towards the reduction of 4-nitrophenylacetic acid is high, predicting a high electrochemical signal since the increase of the peak current is known to be enhanced with high values of $k_{s}$. Preconcentration of nitro species on the electrode surface underlines the interest of $\mathrm{Nafion}^{\circledR}$ to immobilize the catalyst.

Calibration plot and detection limit for 4-nitrophenylacetic acid. The dependence of the electrochemical signal on the concentration of 4-nitrophenylacetic acid was examined by cyclic voltammetry on four different $\left(\mathrm{C}_{5} \mathrm{H}_{5}\right)_{2} \mathrm{Ti}^{\mathrm{IV}}\left(\mathrm{OH}_{2}\right)_{2}{ }^{2+}$-modified electrodes and is given in Figure 3. 


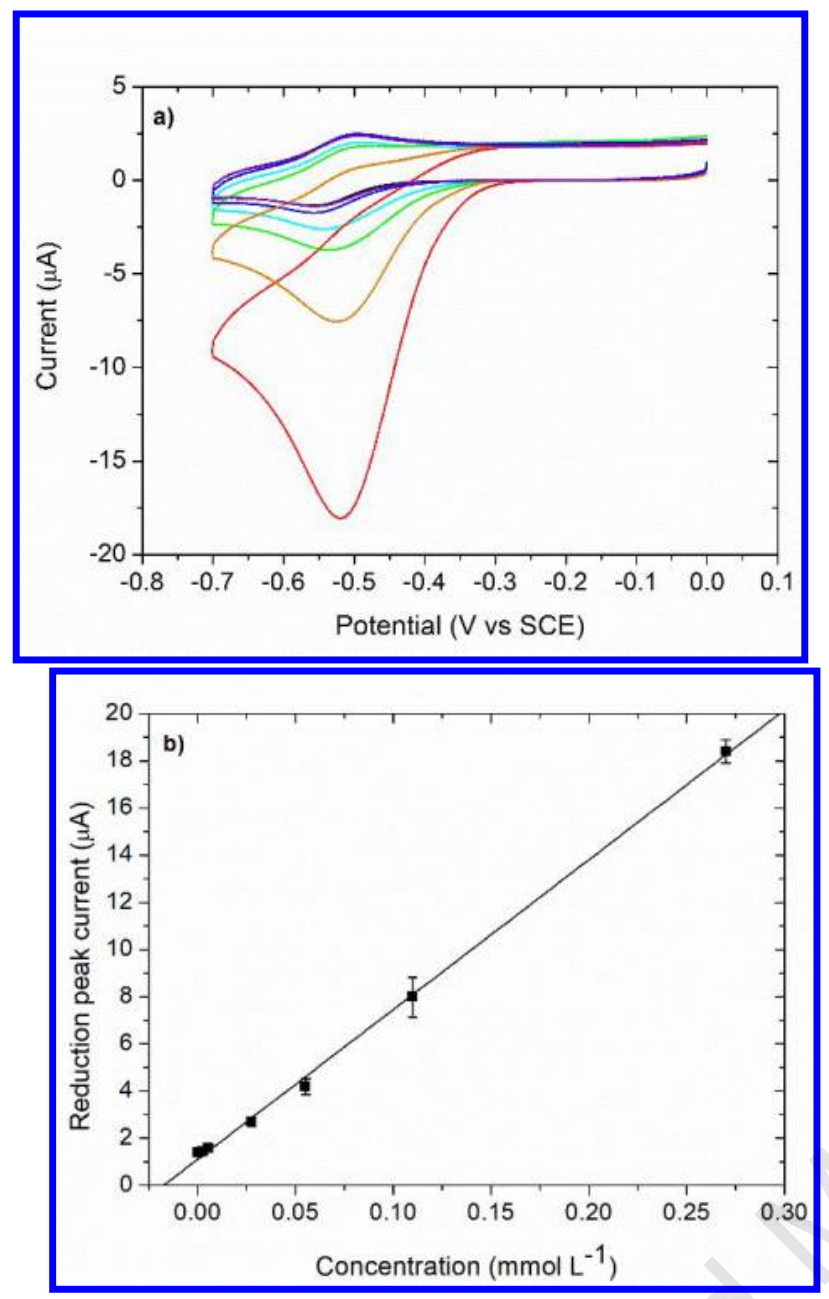

Figure 3. a) Typical cyclic voltammogram in $0.05 \mathrm{~mol} \mathrm{~L}^{-1} \mathrm{H}_{2} \mathrm{SO}_{4}$ of $\left(\mathrm{C}_{5} \mathrm{H}_{5}\right)_{2} \mathrm{Ti}^{\mathrm{IV}}\left(\mathrm{OH}_{2}\right)_{2}{ }^{2+}-$ modified electrode $\left(\left[\mathrm{Nafion}^{\circledR}\right]=1.25 \%\right.$ and $\left.\left[\left(\mathrm{C}_{5} \mathrm{H}_{5}\right)_{2} \mathrm{TiCl}_{2}\right]=8 \times 10^{-5} \mathrm{~mol} \mathrm{~L}^{-1}\right)$ after addition of a $0,0.3,0.5,2.8,5.5,11.0$ and $27.6 \times 10^{-5} \mathrm{~mol} \mathrm{~L}^{-1}\left(0,5,10,50,100,200\right.$ and $\left.500 \times 10^{-4} \mathrm{~g} \mathrm{~L}^{-1}\right)$ solution of 4-nitrophenylacetic acid (Scan rate: $100 \mathrm{mV} \mathrm{s}^{-1}$ ). b) Calibration curve of the sensor and linear fit for a concentration range of 0.3 to $27.6 \times 10^{-5} \mathrm{~mol} \mathrm{~L}^{-1}$. Error bars are based on electrochemical signal given by 4 different modified electrodes with three measures per electrode. The background was subtracted.

The curve is linear in the studied range of 0.3 to $27.6 \times 10^{-5} \mathrm{~mol} \mathrm{~L}^{-1}$ with a correlation coefficient of 0.9994 and can be expressed according to the following equation: Ip $(\mu \mathrm{A})=1.1( \pm 0.1)+6.2( \pm 0.1) \times 10^{4}\left[\right.$ 4-nitrophenylacetic acid] $\left(\mathrm{mol} \mathrm{L}^{-1}\right)$ The limit of detection $(3 \times$ the standard deviation of five blank determinations) was determined from: ${ }^{19}$

$\mathrm{St}-\mathrm{Sb} \geq 3 \sigma$ 
where St is the gross analyte signal, Sb the field blank and $\sigma$ the standard deviation in the field blank.

$\mathrm{St}$ and $\mathrm{Sb}$ were the maximum current intensity of the corresponding peaks.

We found a limit of detection of $4.1 \mu \mathrm{mol} \mathrm{L}^{-1}\left(7.4 \times 10^{-4} \mathrm{~g} \mathrm{~L}^{-1}\right)$ with $\mathrm{Sb}+3 \sigma=1.354 \mu \mathrm{A}$. This value is in the same order of magnitude as limits of detection measured by nitroreductase biosensors for NACs detection $\left(2 \mu \mathrm{mol} \mathrm{L}{ }^{-1}\right) .{ }^{18 a}$ This result shows that low limits of detection could also be reached with such simple cost-effective biomimetic sensor.

Stability and reproducibility. The stability of the $\left(\mathrm{C}_{5} \mathrm{H}_{5}\right)_{2} \mathrm{Ti}^{\mathrm{IV}}\left(\mathrm{OH}_{2}\right)_{2}{ }^{2+}$-modified electrode was checked by cyclic voltammetry experiments (Figure 4). After immersion of the electrode in $0.05 \mathrm{~mol} \mathrm{~L}^{-1} \mathrm{H}_{2} \mathrm{SO}_{4}$ and stabilization of the signal (after 10 cycles), cyclic voltammetry analyses were performed ( 2 measurements of 3 cycles) every $5 \mathrm{~min}$. The electrode was rinsed with an acidic solution or just left in the electrolyte for 5 min between each analysis. 9 different modified electrodes were tested. A seen in Figure 4a, the electrochemical signal corresponding to the maximum of the oxidation peak slowly decreased reaching $80 \%$ of the initial value after 12 analyses. This discrepancy clearly depends on the modified electrode although a decrease was always observed. The same experiments performed with an electrode modified using $1.25 \% \mathrm{Nafion}^{\circledR}$ and $2 \times 10^{-4} \mathrm{~mol} \mathrm{~L}^{-1}\left(\mathrm{C}_{5} \mathrm{H}_{5}\right)_{2} \mathrm{TiCl}_{2}$ led to similar results (Figure S5). This decrease is probably due to the leaching of the Ti catalyst during cycling. It is worth noting that dipping the electrode in the electrolyte between the analyses did not lead to a higher decrease of the electrochemical signal. A better stability is observed with the modified electrode when cyclic voltammetry analyses were performed in the presence of 4-nitrophenylacetic acid (Figure $4 \mathrm{~b}$ ), showing that the electrode could be used several times for the analysis of nitro compounds.

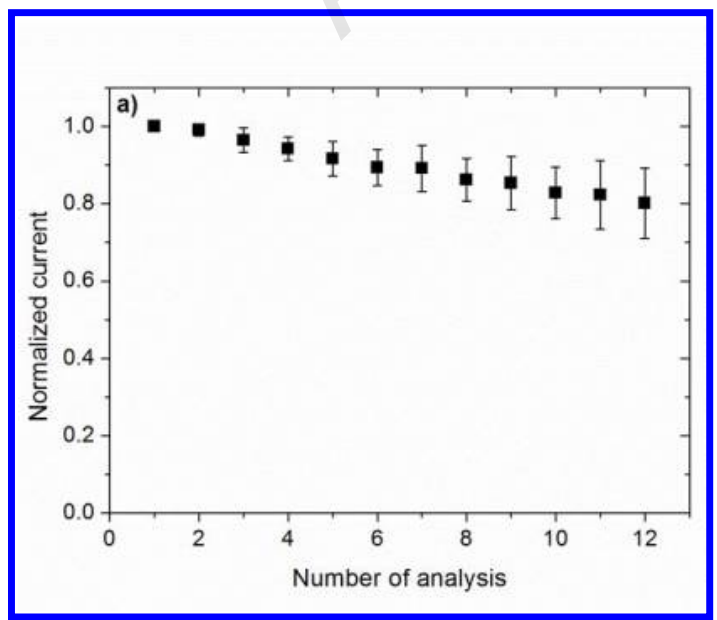


Figure 4. a) Oxidation peak current measured by cyclic voltammetry in $0.05 \mathrm{~mol} \mathrm{~L}^{-1} \mathrm{H}_{2} \mathrm{SO}_{4}$ and normalized by the signal of the first analysis after stabilization of $\left(\mathrm{C}_{5} \mathrm{H}_{5}\right)_{2} \mathrm{Ti}^{\mathrm{IV}}\left(\mathrm{OH}_{2}\right)_{2}{ }^{2+}-$ modified electrode $\left(\left[\mathrm{Nafion}^{\circledR}\right]=1.25 \%\right.$ and $\left.\left[\left(\mathrm{C}_{5} \mathrm{H}_{5}\right)_{2} \mathrm{TiCl}_{2}\right]=8 \times 10^{-5} \mathrm{~mol} \mathrm{~L}^{-1}\right)$ Error bars are based on the electrochemical signal given by 9 different modified electrodes. b) Reduction peak current measured by cyclic voltammetry in $0.05 \mathrm{~mol} \mathrm{~L}^{-1} \mathrm{H}_{2} \mathrm{SO}_{4}$ and normalized according to the first analysis after stabilization of $\left(\mathrm{C}_{5} \mathrm{H}_{5}\right)_{2} \mathrm{Ti}^{\mathrm{IV}}\left(\mathrm{OH}_{2}\right)_{2}{ }^{2+}$-modified electrode $\left(\left[\mathrm{Nafion}^{\circledR}\right]=\right.$ $1.25 \%$ and $\left.\left[\left(\mathrm{C}_{5} \mathrm{H}_{5}\right)_{2} \mathrm{TiCl}_{2}\right]=8 \times 10^{-5} \mathrm{~mol} \mathrm{~L}^{-1}\right)$ after addition of a $5.5 \times 10^{-5} \mathrm{~mol} \mathrm{~L}^{-1}$ solution of 4-nitrophenylacetic acid. Scan rate: $100 \mathrm{mV} \mathrm{s}^{-1} \mathrm{c}$ ) Mean value of the maximum reduction peak current response measured by cyclic voltammetry in $0.05 \mathrm{~mol} \mathrm{~L}^{-1} \mathrm{H}_{2} \mathrm{SO}_{4}$ (2 ${ }^{\text {th }}$ cycle) of 28 different $\left(\mathrm{C}_{5} \mathrm{H}_{5}\right)_{2} \mathrm{Ti}^{\mathrm{IV}}\left(\mathrm{OH}_{2}\right)_{2}{ }^{2+}$-modified electrodes $\left(\left[\mathrm{Nafion}^{\circledR}\right]=1.25 \%\right.$ and $\left[\left(\mathrm{C}_{5} \mathrm{H}_{5}\right)_{2} \mathrm{TiCl}_{2}\right]=8$ $\left.\times 10^{-5} \mathrm{~mol} \mathrm{~L}^{-1}\right)(10$ from electrode 1 and 9 from electrode 2 and 3$)$. A mean value taking into account the 28 data is also given.

The stability of the modified electrode during 4-nitrophenylacetic acid analysis was confirmed by the similitude of cyclic voltammograms performed before and after the establishment of the calibration plot (Figure S6). It is also worth noting that the simplicity and low cost of the electrode modification that could be for example applied to screen-printed electrodes would allow their use as disposable devices. 
Reproducibility experiments were carried out on 3 different glassy carbon electrodes. The electrodes were cleaned and modified 10 or 9 times with the same protocol $\left(\left[\mathrm{Nafion}^{\circledR}\right]=1.25 \%\right.$ and $\left.\left[\left(\mathrm{C}_{5} \mathrm{H}_{5}\right)_{2} \mathrm{TiCl}_{2}\right]=8 \times 10^{-5} \mathrm{~mol} \mathrm{~L}^{-1}\right)$. Each modified electrode was analyzed by cyclic voltammetry and the value of the reduction peak was measured after two stabilization steps of 10 cycles. Only one data on the 29 analyses was not taken into account since the current value was very different from the other electrodes. Results are given in Figure 4c.

The standard deviation is in the range of 14 to $21 \%$ depending on the GC electrode, which is consistent with the difficulty to obtain reproducible modified electrodes using drop-coating of a Nafion ${ }^{\circledR}$ solution. ${ }^{19}$ When different GC electrodes with the same diameters of glass and of carbon are used, the reproducibility is similar than those obtained on a single electrode as it is outlined by the standard deviation found when all the 28 experiments are considered (around $15 \%)$.

Detection of nitroaromatic pollutants. The detection of different nitroaromatic pollutants by the $\left(\mathrm{C}_{5} \mathrm{H}_{5}\right)_{2} \mathrm{Ti}^{\mathrm{IV}}\left(\mathrm{OH}_{2}\right)_{2}{ }^{2+}$-modified electrodes was evaluated. Results are given in Table 1. Ti complex immobilized in the Nafion ${ }^{\circledR}$ film catalyzed nitro derivatives ( $m$-nitrophenol, $p$ nitrotoluene, nitrobenzene, $m$-nitroaniline) that have a reduction potential peak on $\mathrm{Nafion}^{\circledR} / \mathrm{GC}$ electrode slightly shifted in the negative potentials compared with the half wave potential of the $\mathrm{Ti}^{\mathrm{IV} / \mathrm{III}}$ catalyst (from 25 to $95 \mathrm{mV}$ ) (Figure 5a).

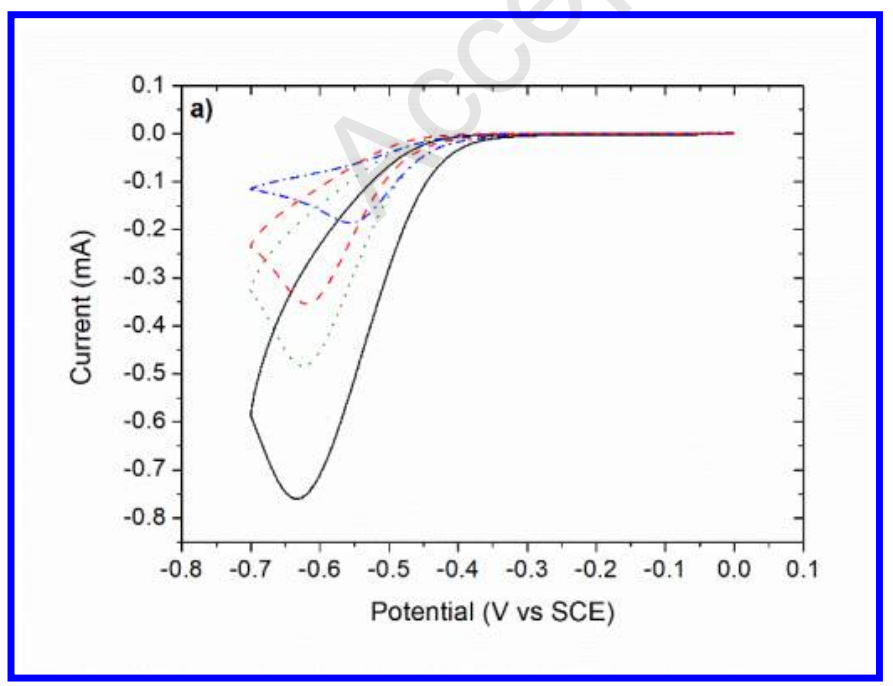




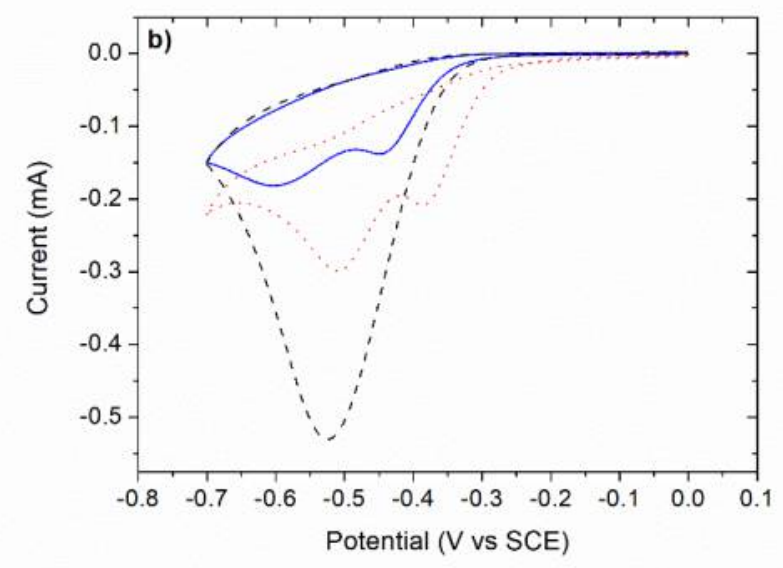

Figure 5. Cyclic voltammograms in $0.05 \mathrm{~mol} \mathrm{~L}^{-1} \mathrm{H}_{2} \mathrm{SO}_{4}$ on a Nafion coated electrode $\left([\right.$ Nafion $]=1.25 \%, 3 \mathrm{~mm}$ diameter) of $0.5 \mathrm{~g} \mathrm{~L}^{-1}$ a) $m$-nitrophenol (-.---), p-nitrotoluene (----), nitrobenzene $(. . . .),$.$m -nitroaniline (-)$.b) 2,4-dinitrotoluene $(-)$, metronidazole $(. . . .$.$) ,$ 2,6-dinitrophenol (-----). Scan rate: $100 \mathrm{mV} \mathrm{s}^{-1}$.

It was also possible to detect nitroaromatic compounds (2,4-dinitrotoluene, metronidazole, 2,6dinitrophenol) with a reduction potential less negative or close to those of the $\mathrm{Ti}^{\mathrm{IV} / I I I}$ complex (Figure 5b). In those cases, the electrochemical signal corresponds to both direct reduction of the nitro group and catalytic process. As for 4-nitrophenylacetic acid, a calibration curve was established (Figure S7) and the detection limit was calculated for each species (Table 1). The sensitivities given by the slope are between 4 and $20 \times 10^{4} \mu \mathrm{A} \mathrm{mol}^{-1} \mathrm{~L}$, depending on the nature of the nitro species. When only the catalytic process occurs, it does not follow the order of the onset values of the reduction peaks ( $m$-nitroaniline $>m$-nitrophenol $>$ nitrobenzene $>p$ nitrotoluene) that is linked to the nature and the position of the electron withdrawing or electron donor groups attached on the phenyl ring, as it could be expected for an outer-sphere mechanism. This result confirms an inner sphere mechanism of the Ti complex. For metronidazole and 2,6-dinitrophenol, a shift of the potential was observed when the concentration of nitro species increases, owing to the competition of the catalytic process with direct reduction. Detection limits of $1-9 \times 10^{-4} \mathrm{~g} \mathrm{~L}^{-1}\left(0.2-5.1 \times 10^{-6} \mathrm{~mol} \mathrm{~L}^{-1}\right)$ were determined. They are of the same order of magnitude than the value obtained with biosensor for 2,4dinitrotoluene and 2,4,6-trinitrotoluene detection $\left(2 \times 10^{-6} \mathrm{~mol} \mathrm{~L}^{-1}\right)$. 
Table 1: Calibration curve equations and detection limits for the nitroaromatic pollutants using the $\left(\mathrm{C}_{5} \mathrm{H}_{5}\right)_{2} \mathrm{Ti}^{\mathrm{IV}}\left(\mathrm{OH}_{2}\right)_{2}{ }^{2+}$-modified electrode

\begin{tabular}{|c|c|c|c|}
\hline Species & $\begin{array}{l}\operatorname{Ip}(\mu \mathrm{A})=\mathrm{f}(\mathrm{X}) \\
\text { with } \mathrm{C}=10^{4} \times[\text { nitro species }](\mathrm{mol} \\
\left.\mathrm{L}^{-1}\right)\end{array}$ & $\begin{array}{l}\text { Correlation } \\
\text { coefficient }\end{array}$ & $\begin{array}{l}\text { Detection limit / } \\
\times 10^{-4} \mathrm{~g} \mathrm{~L}^{-1}\left(\times 10^{-6}\right. \\
\left.\mathrm{mol} \mathrm{L}^{-1}\right)\end{array}$ \\
\hline$m$-nitrophenol & $2.2( \pm 0.1)+4.38( \pm 0.08) \times \mathrm{C}$ & 0.9991 & $2.2(1.6)$ \\
\hline$p$-nitrotoluene & $1.39( \pm 0.09)+6.68( \pm 0.05) \times \mathrm{C}$ & 0.9998 & $4.3(3.1)$ \\
\hline nitrobenzene & $1.7( \pm 0.5)+11.0( \pm 0.3) \times \mathrm{C}$ & 0.9980 & $1.6(1.3)$ \\
\hline$m$-nitroaniline & $0.3( \pm 0.3)+20.6( \pm 0.2) \times \mathrm{C}$ & 0.9998 & $1.8(1.3)$ \\
\hline 2,4-dinitrotoluene & $0.81( \pm 0.07)+10.00( \pm 0.05) \times \mathrm{C}$ & 0.9999 & $3.7(0.2)$ \\
\hline metronidazole & $1.1( \pm 0.6)+19.2( \pm 0.5) \times \mathrm{C}$ & 0.9983 & $1.4(0.8)$ \\
\hline 2,6-dinitrophenol & $-0.2( \pm 0.3)+18.8( \pm 0.3) \times \mathrm{C}$ & 0.9993 & $9.4(5.1)$ \\
\hline
\end{tabular}

The catalytic ability of titanocene to reduce nitro aliphatic compounds was also checked with nitromethane and nitrocyclohexane. No catalytic activity was observed for both compounds (Figure S8) even for nitromethane that has an onset value of the reduction potential around -0.6 $\mathrm{V} / \mathrm{SCE}$, showing that the $\left(\mathrm{C}_{5} \mathrm{H}_{5}\right)_{2} \mathrm{Ti}^{\mathrm{IV}}\left(\mathrm{OH}_{2}\right)_{2}{ }^{2+}$-modified electrode is selective to NACs detection.

\section{CONCLUSIONS}

$\left(\mathrm{C}_{5} \mathrm{H}_{5}\right)_{2} \mathrm{Ti}^{\mathrm{III}}\left(\mathrm{OH}_{2}\right)_{2}{ }^{+}$presents a high catalytic activity towards the reduction of nitroaromatic compounds with a 6-electron process and a high apparent chemical rate constant $k_{1}$ of $1.9 \times 10^{4}$ $\mathrm{mol}^{-1} \mathrm{~L} \mathrm{~s}^{-1}$. We took advantage of this property allowing a constant potential measurement to achieve a sensor for NACs detection. Titanocene was immobilized in a Nafion ${ }^{\circledR}$ film on a glassy carbon electrode, as a first and simple method to highlight the performances of the sensor. Indeed, Nafion ${ }^{\circledR}$ allows a preconcentration of the nitro derivatives at the electrode surface during the analysis. A good stability and reproducibility for an electrode modified by dropcoating of a Nafion ${ }^{\circledR}$ solution are obtained. The modified electrode was able to detect several nitroaromatic pollutants at a fixed potential with a good linearity in the range of 5 to 500 $\times 10^{-4} \mathrm{~g} \mathrm{~L}^{-1}$ and a detection limit around 1-9 $\times 10^{-4} \mathrm{~g} \mathrm{~L}^{-1}\left(0.2-5.1 \times 10^{-6} \mathrm{~mol} \mathrm{~L}^{-1}\right)$ depending on the nature of the analyte. Nitroaliphatic compounds are not detected, underlining the selectivity of the modified electrode for NACs. The sensor is therefore able to give quantitative information about the presence of nitroaromatic pollutants in aqueous solutions, giving rise to 
the NAC index, as referred to the phenol index used for the quantification of phenolic compounds in water quality monitoring. Since NACs are unnatural species that are often biorecalcitrant owing to the presence of the nitro group into their structure, a fast detection on pollution by NACs is required in water quality monitoring.

\section{ASSOCIATED CONTENT}

\section{Supporting information}

Preparation of the modified electrode and optimization steps; kinetics of nitro reduction by titanocene; stability of the modified electrode; detection of nitroaromatic pollutants.

\section{ACKNOWLEDGMENTS}

Profs. I Svir and C. Amatore are warmly thanked for providing us the KISSA 1D software package, which was used for the mechanistic simulations of the voltammograms. Research work financially supported by the ministry of defense - Direction Générale de l'Armement.

\section{REFERENCES}

1. Sun, J.-H.; Sun, S.-P.; Fan, M.-H.; Guo, H.-Q.; Qiao, L.-P.; Sun, R.-X., A kinetic study on the degradation of p-nitroaniline by Fenton oxidation process. J. Hazard. Mater. 2007, 148 (1-2), 172-177.

2. (a) Hawari, J.; Beaudet, S.; Halasz, A.; Thiboutot, S.; Ampleman, G., Microbial degradation of explosives: biotransformation versus mineralization. Appl. Microbiol. Biotechnol. 2000, 54 (5), 605-618; (b) Labana, S.; Pandey, G.; Paul, D.; Sharma, N. K.; Basu, A.; Jain, R. K., Pot and Field Studies on Bioremediation of p-Nitrophenol Contaminated Soil Using Arthrobacter protophormiae RKJ100. Environ. Sci.Technol. 2005, 39 (9), 3330-3337.

3. (a) Purohit, V.; Basu, A. K., Mutagenicity of Nitroaromatic Compounds. Chem. Res. Toxicol. 2000, 13 (8), 673-692; (b) Padda, R. S.; Wang, C.; Hughes, J. B.; Kutty, R.; Bennett, G. N., Mutagenicity of nitroaromatic degradation compounds. Environ. Toxicol. Chem. 2003, 22 (10), 2293-2297.

4. (a) Kristanti, R. A.; Kanbe, M.; Hadibarata, T.; Toyama, T.; Tanaka, Y.; Mori, K., Isolation and characterization of 3-nitrophenol-degrading bacteria associated with rhizosphere of Spirodela polyrrhiza. Environ.Sci.Pollut.Res. 2012, 19 (5), 1852-1858; (b) Keith, L.; Telliard, W., ES\&T Special Report: Priority pollutants: I-a perspective view. Environ. Sci. 
Technol. 1979, 13 (4), 416-423; (c) Rosenfeld, J. K.; Plumb, R. H., Jr., Groundwater contamination at wood treatment facilities. Ground Water Monit. Rev. 1991, 11 (1), 133-40.

5. (a) Warzecha, M.; Calvo-Castro, J.; Kennedy, A. R.; MacPherson, A. N.; Shankland, K.; Shankland, N.; McLean, A. J.; McHugh, C. J., Detection of nitroaromatic vapours with diketopyrrolopyrrole thin films: exploring the role of structural order and morphology on thin film properties and fluorescence quenching efficiency. Chem.Commun. 2015, 51 (6), 1143 1146; (b) Venkatramaiah, N.; Pereira, C. F.; Mendes, R. F.; Paz, F. A. A.; Tome, J. P. C., Phosphonate Appended Porphyrins as Versatile Chemosensors for Selective Detection of Trinitrotoluene. Anal. Chem. 2015, 87 (8), 4515-4522; (c) Pramanik, S.; Zheng, C.; Zhang, X.; Emge, T. J.; Li, J., New Microporous Metal-Organic Framework Demonstrating Unique Selectivity for Detection of High Explosives and Aromatic Compounds. J. Am. Chem. Soc. 2011, 133 (12), 4153-4155.

6. Moore, D. S., Instrumentation for trace detection of high explosives. Rev. Sci. Instrum. 2004, 75 (8), 2499-2512.

7. (a) Sabo, M.; Malaskova, M.; Harmathova, O.; Hradski, J.; Masar, M.; Radjenovic, B.; Matejcik, S., Direct Liquid Sampling for Corona Discharge Ion Mobility Spectrometry. Anal. Chem. 2015, 87 (14), 7389-7394; (b) Zamora, D.; Amo-Gonzalez, M.; Lanza, M.; Fernandez de la Mora, G.; Fernandez de la Mora, J., Reaching a Vapor Sensitivity of 0.01 Parts Per Quadrillion in the Screening of Large Volume Freight. Anal. Chem. 2018, 90 (4), 2468-2474. 8. Zhang, H.-X.; Zhang, J.-H., Voltammetric detection of nitroaromatic compounds using carbon-nanomaterials-based electrodes. Can. J. Chem. 2011, 89 (1), 8-12.

9. Zhang, H.-X.; Chen, Q.; Wen, R.; Hu, J.-S.; Wan, L.-J., Effect of polycyclic aromatic hydrocarbons on detection sensitivity of ultratrace nitroaromatic compounds. Anal. Chem. 2007, 79 (5), 2179-2183.

10. Yuan, C.-X.; Fan, Y.-R.; Tao, Z.; Guo, H.-X.; Zhang, J.-X.; Wang, Y.-L.; Shan, D.-L.; Lu, X.-Q., A new electrochemical sensor of nitro aromatic compound based on threedimensional porous Pt-Pd nanoparticles supported by graphene-multiwalled carbon nanotube composite. Biosens. Bioelectron. 2014, 58, 85-91.

11. Chen, X.; Cheng, X.; Gooding, J. J., Detection of Trace Nitroaromatic Isomers Using Indium Tin Oxide Electrodes Modified Using $\beta$-Cyclodextrin and Silver Nanoparticles. Anal. Chem. 2012, 84 (20), 8557-8563.

12. Guo, C. X.; Lei, Y.; Li, C. M., Porphyrin functionalized graphene for sensitive electrochemical detection of ultratrace explosives. Electroanalysis 2011, 23 (4), 885-893. 
13. Wang, F.; Wang, W.; Liu, B.; Wang, Z.; Zhang, Z., Copolypeptide-doped polyaniline nanofibers for electrochemical detection of ultratrace trinitrotoluene. Talanta 2009, 79 (2), 376382.

14. Zhang, H.-X.; Cao, A.-M.; Hu, J.-S.; Wan, L.-J.; Lee, S.-T., Electrochemical sensor for detecting ultratrace nitroaromatic compounds using mesoporous SiO2-modified electrode. Anal.Chem. 2006, 78 (6), 1967-1971.

15. Forzani, E. S.; Lu, D.; Leright, M. J.; Aguilar, A. D.; Tsow, F.; Iglesias, R. A.; Zhang, Q.; Lu, J.; Li, J.; Tao, N., A hybrid electrochemical-colorimetric sensing platform for detection of explosives. L.Am.Chem.Soc. 2009, 131 (4), 1390-1391.

16. Riskin, M.; Tel-Vered, R.; Bourenko, T.; Granot, E.; Willner, I., Imprinting of molecular recognition sites through electropolymerization of functionalized $\mathrm{Au}$ nanoparticles: development of an electrochemical TNT sensor based on $\pi$-donor-acceptor interactions. $J$. Am. Chem.Soc. 2008, 130 (30), 9726-9733.

17. Gu, Y.; Yan, X.; Li, C.; Zheng, B.; Li, Y.; Liu, W.; Zhang, Z.; Yang, M., Biomimetic sensor based on molecularly imprinted polymer with nitroreductase-like activity for metronidazole detection. Biosens. Bioelectron. 2016, 77, 393-399.

18. (a) Naal, Z.; Park, J. H.; Bernhard, S.; Shapleigh, J. P.; Batt, C. A.; Abruna, H. D., Amperometric TNT Biosensor Based on the Oriented Immobilization of a Nitroreductase Maltose Binding Protein Fusion. Anal. Chem. 2002, 74 (1), 140-148; (b) O'Mahony, A. M.; Valdes-Ramirez, G.; Windmiller, J. R.; Samek, I. A.; Wang, J., Orthogonal Detection of Nitroaromatic Explosives via Direct Voltammetry Coupled to Enzyme-Mediated Biocatalysis. Electroanalvsis 2012, 24 (9), 1811-1816.

19. Boulkroune, M.; Lemaire, A.; Chibani, A.; Geneste, F., Monocopper complex based on N-tripodal ligand immobilized in a Nafion film for biomimetic detection of catechols: Application to dopamine. Electrochim. Acta 2016, 221, 80-85.

20. (a) Saidi, I.; Soutrel, I.; Floner, D.; Fourcade, F.; Bellakhal, N.; Amrane, A.; Geneste, F., Indirect electroreduction as pretreatment to enhance biodegradability of metronidazole. $J$. Hazard Mater. 2014, 278, 172-179; (b) Saidi, I.; Soutrel, I.; Fourcade, F.; Amrane, A.; Bellakhal, N.; Geneste, F., Electrocatalytic reduction of metronidazole using titanocene/Nafion-modified graphite felt electrode. Electrochim.Acta 2016, 191, 821-831; (c) Zaghdoudi, M.; Fourcade, F.; Soutrel, I.; Floner, D.; Amrane, A.; Maghraoui-Meherzi, H.; Geneste, F., Direct and indirect electrochemical reduction prior to a biological treatment for dimetridazole removal. L_Hazard. Mater. 2017, 335, 10-17. 
21. (a) Amatore, C.; Klymenko, O.; Svir, I., A new strategy for simulation of electrochemical mechanisms involving acute reaction fronts in solution: Principle. Electrochem.Commun. 2010, 12 (9), 1170-1173; (b) Amatore, C.; Klymenko, O.; Svir, I., A new strategy for simulation of electrochemical mechanisms involving acute reaction fronts in solution: Application to model mechanisms. Electrochem. Commun. 2010, 12 (9), 1165-1169. 22. Mokdsi, G.; Harding, M. M., Water soluble, hydrolytically stable derivatives of the antitumor drug titanocene dichloride and binding studies with nucleotides. J. Organomet. Chem. 1998, 565 (1-2), 29-35.

23. Kuhn, A.; Conradie, J., Electrochemical and density functional theory study of bis(cyclopentadienyl) mono( $\beta$-diketonato) titanium(IV) cationic complexes. Electrochim. Acta 2010, 56 (1), 257-264.

24. He, W. Y.; Fontmorin, J. M.; Hapiot, P.; Soutrel, I.; Floner, D.; Fourcade, F.; Amrane, A.; Geneste, F., A new bipyridyl cobalt complex for reductive dechlorination of pesticides. Electrochim Acta 2016, 207, 313-320.

25. Bard, A. J.; Faulkner, L. R., Electrochemical Methods: Fundamentals and Applications. John Wiley \& Sons, Inc: New York, 2001.

26. Martin, C. R.; Rubinstein, I.; Bard, A. J., Polymer films on electrodes. 9. Electron and mass transfer in Nafion films containing tris(2,2'-bipyridine)ruthenium(2+). J. Am. Chem. Soc. 1982, 104 (18), 4817-24.

27. Fontaine, O.; Lagrost, C.; Ghilane, J.; Martin, P.; Trippe, G.; Fave, C.; Lacroix, J. C.; Hapiot, P.; Randriamahazaka, H. N., Mass transport and heterogeneous electron transfer of a ferrocene derivative in a room-temperature ionic liquid. J. Electroanal. Chem. 2009, 632 (1-2), 88-96.

28. Saveant, J.-M., Elements of Molecular and Biomolecular Electrochemistry: An Electrochemical Approach to Electron Transfer Chemistry. Wiley-Interscience: New Jersey, 2006.

29. (a) Chollet, M.; Burgot, J.-L.; Moinet, C., Selective indirect electroreduction of 5(nitrophenyl)-1,2-dithiole-3-thiones. Electrochim. Acta 1998, 44 (2-3), 201-206; (b) Floner, D.; Laglaine, L.; Moinet, C., Indirect electrolysis involving an ex-cell two-phase process. Reduction of nitrobenzenes with a titanium complex as mediator. Electrochim. Acta 1996, 42 (4), 525-529.

30. (a) Guadalupe, A. R.; Liu, K. E.; Abruna, H. D., Transport properties of cationic dyes in Nafion films: unusually high diffusion coefficients and aggregation effects. Electrochim. Acta 1991, 36 (5-6), 881-7; (b) Snowden, M. E.; Edwards, M. A.; Rudd, N. C.; Macpherson, J. 
V.; Unwin, P. R., Intrinsic electrochemical activity of single walled carbon nanotube-Nafion assemblies. Phys. Chem. Chem. Phvs. 2013, 15 (14), 5030-5038.

For TOC only

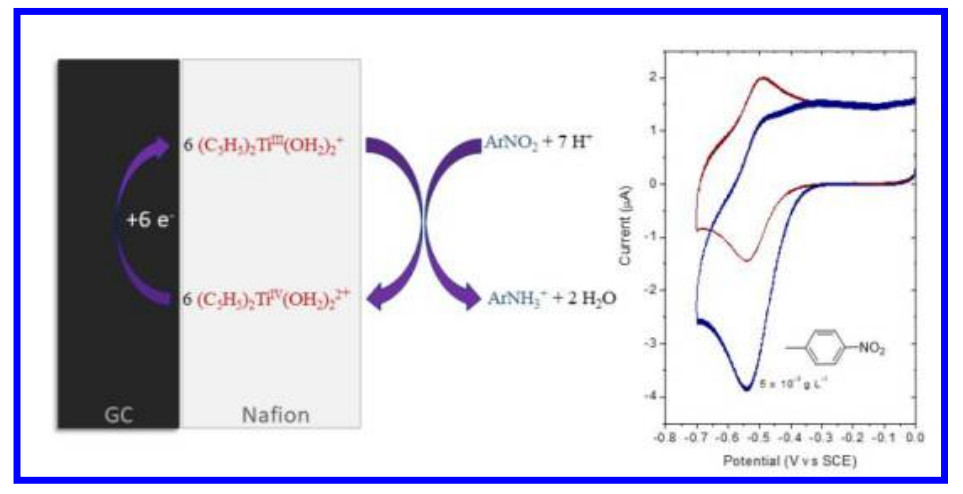

